\title{
Effectiveness of nootropic drugs with cholinergic activity in treatment of cognitive deficit: a review
}

\author{
This article was published in the following Dove Press journal: \\ Journal of Experimental Pharmacology \\ II December 2012 \\ Number of times this article has been viewed
}

\author{
Luisa Colucci ${ }^{1,2}$ \\ Massimiliano Bosco ${ }^{2}$ \\ Antonio Rosario Ziello ${ }^{1,2}$ \\ Raffaele Rea ${ }^{1,2}$ \\ Francesco Amenta' \\ Angiola Maria Fasanaro 2 \\ 'Centro di Ricerche Cliniche, \\ Telemedicina e Telefarmacia, \\ Università di Camerino, Camerino, \\ ${ }^{2}$ Unità Valutazione Alzheimer, \\ Naples, Italy
}

\begin{abstract}
Nootropics represent probably the first "smart drugs" used for the treatment of cognitive deficits. The aim of this paper is to verify, by a systematic analysis of the literature, the effectiveness of nootropics in this indication. The analysis was limited to nootropics with cholinergic activity, in view of the role played by acetylcholine in learning and memory. Acetylcholine was the first neurotransmitter identified in the history of neuroscience and is the main neurotransmitter of the peripheral, autonomic, and enteric nervous systems. We conducted a systematic review of the literature for the 5-year period 2006-2011. From the data reported in the literature, it emerges that nootropics may be an effective alternative for strengthening and enhancing cognitive performance in patients with a range of pathologies. Although nootropics, and specifically the cholinergic precursors, already have a long history behind them, according to recent renewal of interest, they still seem to have a significant therapeutic role. Drugs with regulatory indications for symptomatic treatment of Alzheimer's disease, such as cholinesterase inhibitors and memantine, often have transient effects in dementia disorders. Nootropics with a cholinergic profile and documented clinical effectiveness in combination with cognate drugs such as cholinesterase inhibitors or alone in patients who are not suitable for these inhibitors should be taken into account and evaluated further.
\end{abstract}

Keywords: cholinergic nootropics, cognitive function, dementia

\section{Introduction}

Nootropics, also referred to as "smart drugs", are compounds developed over three decades and probably the first to be used for the treatment of cognitive deficits. The term nootropic (from "noos," meaning "to mind" and "tropein," meaning "to monitor") is used to define, in a broad sense, any substance to which is attributed a positive action on cognition. ${ }^{1}$ These kinds of substances, over time, have included a number of agents, eg, dopaminergic and serotonergic drugs. However, in this work, our specific goal is to analyze cholinergically active nootropics. The reason for this choice lies in the crucial role played by acetylcholine in learning and memory. ${ }^{2}$

Acetylcholine could be defined as the first identified neurotransmitter in the history of neuroscience ${ }^{3}$ and the main neurotransmitter in the peripheral, autonomic, and enteric nervous systems. ${ }^{2}$ The observation in the cerebral cortex of patients suffering from Alzheimer's disease of a reduction in choline acetyltransferase, a biosynthetic enzyme of acetylcholine, as well as subsequent preclinical and clinical evidence, have led to the development of the so-called "cholinergic hypothesis"4 of cognitive dysfunction. Starting from this hypothesis, and from the correlation between brain levels of acetylcholine and cognitive performance, different classes of drugs, 
such as inhibitors of acetylcholinesterase/cholinesterase, cholinergic antagonists of muscarinic receptors, muscarinic cholinergic inhibitors, and acetylcholine precursors were developed. ${ }^{5}$

The purpose of this investigation was to verify the effectiveness of nootropics with a cholinergic profile on cognitive function, and particularly their efficacy in slowing the progression of dementia, using a systematic analysis of the literature.

\section{Search methods}

We conducted a systematic review of the literature for the 5-year period of 2006-2011 in the PubMed and Medline databases, using the search terms "piracetam and cognitive function," "oxiracetam and cognitive function," "lecithin and cognitive function," "acetyl carnitine and cognitive function," "choline alfoscerate and cognitive function," "citicoline and cognitive function," "CDP-choline and cognitive function," "nootropics and Alzheimer's disease," and "nootropics and vascular dementia."

The limits applied to the research were English language articles and abstracts, with keywords found in the title or abstract. We considered only randomized monitored trials, reviews, and meta-analyses. The articles were then selected using the criteria of the Newcastle-Ottawa Scale ${ }^{6}$ that enables assessment of the methodological quality of comparative and case-control studies. Overall, study quality was defined as poor (score 0-4), moderate (5-6), or good (7-9). From 267 selected abstracts, 176 were considered to be relevant to the subject, and 26 met the criterion of "adequacy and representativeness" indicated by Newcastle-Ottawa score. Therefore, the results refer to the data from these 26 articles.

\section{Piracetam and cognitive function}

Of seven articles overall, only four met the criterion of "adequacy and representativeness" according to the Newcastle-Ottawa Scale (Table 1). Piracetam, initially approved for the treatment of dizziness and cognitive impairment associated with ageing, ${ }^{1}$ was subsequently used widely to improve cognition in patients with encephalopathy of different origins (traumatic brain injury, stroke, ischemia, complications following bypass surgery) and prevention of cognitive dysfunction following anesthesia. Side effects were few and transient, and included insomnia, somnolence, and agitation. ${ }^{7,8}$ Piracetam modulates the effects of inhibitors and excitatory neurotransmitters in the brain. It has also been suggested that it has a role in increasing the availability of oxygen and permeability of the mitochondrial cell membrane in the intermediate stages of the Krebs cycle., ${ }^{9,10}$ Positive effects of piracetam in the prevention of cognitive dysfunction (especially memory) that often occur after surgery under general anesthesia were also reported.

A recent study in 250 children, of whom 123 comprised an experimental group and 127 comprised a control group, showed that intravenous administration of piracetam $30 \mathrm{mg} / \mathrm{kg}$ reduced the cognitive dysfunction produced by anesthesia. ${ }^{11}$ The study included patients receiving different anesthetic medications for various surgical procedures. The children were premedicated with atropine and diazepam. Depending on the anesthetic used, the patients were divided into the following groups: ketamine alone, ketamine and hydroxybutyrate, thiopentone and hydroxybutyrate, propofol, and hydroxybutyrate. The children's cognitive function was examined preoperatively and for 10 consecutive days postoperatively. Different types of anesthesia are known to affect memory function in children, and in this study

Table I Piracetam and cognitive function

\begin{tabular}{|c|c|c|c|c|}
\hline Reference & Title & Main results & Study type & $\begin{array}{l}\text { Patients } \\
\text { randomized }\end{array}$ \\
\hline Holinski et al ${ }^{18}$ & $\begin{array}{l}\text { Cerebroprotective effect of piracetam } \\
\text { in patients undergoing open heart } \\
\text { surgery }\end{array}$ & $\begin{array}{l}\text { Piracetam has no cerebroprotective } \\
\text { effects in patients undergoing open } \\
\text { heart cardiopulmonary bypass } \\
\text { surgery }\end{array}$ & $\begin{array}{l}\text { Clinical trial, } \\
\text { randomized, } \\
\text { double-blind }\end{array}$ & 88 patients \\
\hline $\begin{array}{l}\text { Malykh and } \\
\text { Sadaie' }\end{array}$ & $\begin{array}{l}\text { Piracetam and piracetam-like drugs: from } \\
\text { basic science to novel clinical applications } \\
\text { to central nervous system disorders }\end{array}$ & $\begin{array}{l}\text { A neuroprotective effect of piracetam } \\
\text { in treatment of cerebrovascular and } \\
\text { cognitive disorders of traumatic origin }\end{array}$ & Review & \\
\hline Fesenko"I & $\begin{array}{l}\text { Piracetam improves children's } \\
\text { memory after general } \\
\text { anesthesia }\end{array}$ & $\begin{array}{l}\text { Intravenously administered piracetam } \\
\text { reduces cognitive dysfunction produced } \\
\text { by anesthesia }\end{array}$ & $\begin{array}{l}\text { Clinical trial, } \\
\text { randomized, } \\
\text { double-blind }\end{array}$ & 250 children \\
\hline Holinski et al'14 & $\begin{array}{l}\text { Cerebroprotective effect of } \\
\text { piracetam in patients undergoing } \\
\text { coronary artery bypass surgery }\end{array}$ & $\begin{array}{l}\text { Piracetam has cerebroprotective effects } \\
\text { in patients undergoing non-open heart } \\
\text { cardiopulmonary bypass surgery }\end{array}$ & $\begin{array}{l}\text { Clinical trial, } \\
\text { randomized, } \\
\text { double-blind }\end{array}$ & 120 patients \\
\hline
\end{tabular}


piracetam was effective for prevention of postoperative cognitive dysfunction after general anesthesia in children.

Piracetam has been shown to be effective after cardiopulmonary bypass, when quality of life is generally altered for a long time. ${ }^{12,13} \mathrm{~A}$ protective effect was also found after heart surgery, but not after open heart surgery. ${ }^{14-16}$ In a double-blind study, 120 patients with cardiopulmonary disease were randomly assigned to an experimental group or to a control group. Patients were excluded if they had insulindependent diabetes mellitus, renal insufficiency requiring dialysis, a history of transient ischemic attacks, or complete stroke. At the start of surgery, they received an intravenous infusion of piracetam $12 \mathrm{~g}$ in $60 \mathrm{~mL}$ of saline or $60 \mathrm{~mL}$ of saline alone over 30 minutes. Cognitive function was evaluated the day before surgery and on postoperative day 3 . The experimental group scored much better than the control group on cognitive testing. ${ }^{14}$ However, positive results have not been replicated in cases of open heart cardiopulmonary bypass intervention. ${ }^{17}$ The protective effects of piracetam in the brain have also been highlighted in a meta-analysis of 19 randomized clinical trials including 1488 subjects with a range of memory disorders related to age or dementia. The analysis showed significant improvements in Clinical Global Impression-Change scores in individuals treated with piracetam compared with those who had received placebo. ${ }^{8}$ Favorable effects were also reported in patients with mild cognitive impairment. ${ }^{17}$ A systematic analysis revealed no cerebroprotective effect of piracetam in patients undergoing open heart surgery. ${ }^{18}$ No effects were found in patients with Down syndrome ${ }^{19}$ or in cocaine addicts with withdrawal syndrome, in whom piracetam seems, inexplicably, to increase dependence. ${ }^{20}$

\section{Oxiracetam and cognitive function}

Our systematic analysis revealed a single article on oxiracetam meeting our inclusion criteria (Table 2), showing a favorable pharmacokinetic profile, bioavailability of the active compound, and absence of side effects. ${ }^{1}$ Administration of oxiracetam for 2-6 months in a population older than 65 years improved some cognitive parameters, including speed of reaction time and attentional matrices. ${ }^{21}$ The authors suggested that oxiracetam is effective in the treatment of agerelated cognitive decline and improves the ability to process information, but there was no demonstrated benefit in patients with Alzheimer's disease..$^{22}$ However, the study lasted only one month, so it would be necessary to undertake a more extended evaluation. ${ }^{23}$

\section{Acetylcholine precursors and cognitive function}

This class of drugs induces durable and sustained activation of postsynaptic acetylcholine receptors. ${ }^{3}$ Among these drugs, lecithin, citicoline (cytidine 5'-diphosphocholine, CDPcholine), acetyl-carnitine (acetyl-L-carnitine), and choline alfoscerate (L-alpha glycerylphosphorylcholine) have been used, primarily in Europe, for treating cognitive deficits of vascular or degenerative origin.

\section{Lecithin and cognitive function}

Only two articles met our criteria for inclusion in the present study (Table 3). The authors of these papers documented how use of lecithin, after the first exciting results, has not really helped to improve the cognitive deficits of treated patients in a significant manner. ${ }^{3,24}$ It is not clear why this therapy failed, considering that preclinical studies showed that lecithin increases acetylcholine levels, even if its mechanism of action was not demonstrated..$^{25}$ In spite of the hypothesis that lecithin supplementation may be helpful in improving cognitive function, ${ }^{3}$ stronger evidence should be provided to support this assumption.

\section{Citicoline and cognitive function}

Of five items emerging from our systematic analysis, only four met the Newcastle-Ottawa criteria (Table 4). Citicoline is an intermediary in the biosynthesis of phosphatidylcholine, an important component of the neuronal cell membrane. During ischemia, phosphatidylcholine is split into fatty acids and free radicals that potentiate ischemic injury. ${ }^{26}$ Given that its functions include repair of the neural membrane by synthesis of phosphatidylcholine, reduction of accumulation of the fat responsible for increasing cognitive deficit, and increasing acetylcholine levels, ${ }^{27}$ citicoline has been used widely

Table 2 Oxiracetam and cognitive function

\begin{tabular}{llll}
\hline Reference & Title & Main results & \multicolumn{1}{c}{$\begin{array}{l}\text { Patients } \\
\text { randomized }\end{array}$} \\
\hline Malykh and & Piracetam and piracetam-like drugs: from basic & Oxiracetam improves cognitive & Review \\
Sadaie' & science to novel clinical applications to central & performances except in patients \\
& nervous system disorders & with dementia & \\
\hline
\end{tabular}


Table 3 Lecithin and cognitive function

\begin{tabular}{|c|c|c|c|c|}
\hline Reference & Title & Main results & Study type & $\begin{array}{l}\text { Patients } \\
\text { randomized }\end{array}$ \\
\hline $\begin{array}{l}\text { Amenta and } \\
\text { Tayebati }^{2}\end{array}$ & $\begin{array}{l}\text { Pathways of acetylcholine synthesis, } \\
\text { transport, and release as targets for } \\
\text { treatment of adult-onset cognitive } \\
\text { dysfunction }\end{array}$ & $\begin{array}{l}\text { The data suggest that lecithin does } \\
\text { not improve cognitive deficit in } \\
\text { treated patients }\end{array}$ & Review & NA \\
\hline Parnetti et $\mathrm{al}^{24}$ & $\begin{array}{l}\text { Cholinergic precursors in the treatment } \\
\text { of cognitive impairment of vascular origin: } \\
\text { ineffective approaches or need for } \\
\text { re-evaluation? }\end{array}$ & $\begin{array}{l}\text { The data suggest that lecithin does } \\
\text { not improve cognitive deficit in } \\
\text { treated patients }\end{array}$ & Review & NA \\
\hline
\end{tabular}

in patients who have suffered a stroke. In such subjects, a neuroprotective effect contributing to significant improvement in temporal orientation, attention tasks, and executive function has been reported, along with an ability, albeit in the experimental setting, to assist in neural repair. ${ }^{28}$

A recent review documents the activity of citicoline not only on patients with ischemic stroke but also in those with traumatic brain injury, probably because of its effect on edema. Citicoline reduced the duration of hospitalization and improved the recovery of neurological function and level of consciousness. ${ }^{29}$ These data are consistent with a Cochrane meta-analysis reporting on 13 studies carried out from the 1970s to the early 2000s, all of which demonstrated the effectiveness of citicoline in the treatment of cognitive, emotional, and behavioral disorders, ${ }^{30}$ which has been attributed to the effect of citicoline on metabolic activation. ${ }^{31}$ These effects, as documented in a recent review, are found in both healthy subjects as well as in patients with dementia of degenerative and/or vascular origin and in patients with cerebrovascular disease. ${ }^{29}$ In patients with cerebrovascular disease, treatment with citicoline has shown improvements in perceptual-motor and attentional functioning, and in stabilization of behavior. ${ }^{32-34}$ In patients with vascular dementia, citicoline has been shown to promote a significant increase in cerebral blood flow, ${ }^{35}$ and to improve cognitive and circulatory function in patients with Alzheimer's disease. ${ }^{36}$ Based on these observations, the possibility of use of citicoline in the treatment of Parkinson's dementia has been suggested. ${ }^{37}$

\section{Acetyl-carnitine and cognitive function}

Our search terms for acetyl-carnitine identified eight papers, of which six met the standards of "adequacy and representativeness of the case" according to Newcastle-Ottawa criteria (Table 5). Acetyl-L-carnitine probably has a role in slowing development of cognitive deficits in patients with minimal hepatic encephalopathy, a disease which is not easily recognizable and manifests mainly as psychomotor symptoms accompanied by mild cognitive deficits. ${ }^{38} \mathrm{~A}$ double-blind, randomized, case-control study in 67 patients reported increased energy and well-being and decreased anxiety and depression in an experimental group of 33 patients treated for 90 days with acetyl-carnitine $2 \mathrm{~g}$ twice daily. ${ }^{39}$ The inclusion criterion for that study was a diagnosis of cirrhosis, based

Table 4 Citicoline and cognitive function

\begin{tabular}{|c|c|c|c|c|}
\hline Reference & Title & Main results & Study type & $\begin{array}{l}\text { Patients } \\
\text { randomized }\end{array}$ \\
\hline Secades $^{29}$ & $\begin{array}{l}\text { Citicoline: pharmacological and } \\
\text { clinical review, } 2010 \text { update }\end{array}$ & $\begin{array}{l}\text { A neuroprotective effect of citicoline; } \\
\text { it improves cognitive performance in healthy } \\
\text { patients and in patients with dementia }\end{array}$ & Review & NA \\
\hline $\begin{array}{l}\text { Alvarez-Sabín } \\
\text { and Román }\end{array}$ & $\begin{array}{l}\text { Citicoline in vascular cognitive } \\
\text { impairment and vascular dementia } \\
\text { after stroke }\end{array}$ & $\begin{array}{l}\text { A neuroprotective effect of citicoline; } \\
\text { it improves cognitive performances in healthy } \\
\text { patients and in patients with dementia }\end{array}$ & Review & NA \\
\hline Vale $^{37}$ & $\begin{array}{l}\text { Current management of cognitive } \\
\text { dysfunction in Parkinson's disease: } \\
\text { how far have we come? }\end{array}$ & $\begin{array}{l}\text { The author proposes use of citicoline } \\
\text { in Parkinson's dementia }\end{array}$ & Meta analysis & NA \\
\hline Parnetti et $\mathrm{al}^{24}$ & $\begin{array}{l}\text { Cholinergic precursors in treatment } \\
\text { of cognitive impairment of vascular } \\
\text { origin: ineffective approaches or need } \\
\text { for re-evaluation? }\end{array}$ & $\begin{array}{l}\text { The data suggest citicoline improves } \\
\text { cognitive performances in patients } \\
\text { with dementia (of neurodegenerative } \\
\text { and vascular origin) }\end{array}$ & Review & NA \\
\hline
\end{tabular}


Table 5 Acetyl-carnitine and cognitive function

\begin{tabular}{|c|c|c|c|c|}
\hline Reference & Title & Main results & Study type & $\begin{array}{l}\text { Patients } \\
\text { randomized }\end{array}$ \\
\hline $\begin{array}{l}\text { Malaguarnera } \\
\text { et } \mathrm{al}^{39}\end{array}$ & $\begin{array}{l}\text { Acetyl-L-carnitine reduces depression } \\
\text { and improves quality of life in patients } \\
\text { with minimal hepatic encephalopathy }\end{array}$ & $\begin{array}{l}\text { Acetyl-carnitine improves cognitive } \\
\text { functions in patients with minimal } \\
\text { hepatic encephalopathy; it increases } \\
\text { energy and wellness and reduces } \\
\text { anxiety and depression }\end{array}$ & $\begin{array}{l}\text { Clinical trial, } \\
\text { randomized, } \\
\text { double-blind }\end{array}$ & 67 patients \\
\hline $\begin{array}{l}\text { Malaguarnera } \\
\text { et } \mathrm{al}^{40}\end{array}$ & $\begin{array}{l}\text { Acetyl-L-carnitine treatment in minimal } \\
\text { hepatic encephalopathy }\end{array}$ & $\begin{array}{l}\text { Acetyl-carnitine improves cognitive } \\
\text { function in patients with minimal } \\
\text { hepatic encephalopathy }\end{array}$ & $\begin{array}{l}\text { Clinical trial, } \\
\text { randomized, } \\
\text { double-blind }\end{array}$ & 125 patients \\
\hline $\begin{array}{l}\text { Mancuso } \\
\text { et } \mathrm{al}^{44}\end{array}$ & $\begin{array}{l}\text { Natural antioxidants in Alzheimer's } \\
\text { disease }\end{array}$ & $\begin{array}{l}\text { Authors suggest use of acetyl-carnitine } \\
\text { in neurodegenerative disease because } \\
\text { it can reduce or block typical } \\
\text { neuronal death }\end{array}$ & Review & NA \\
\hline $\begin{array}{l}\text { Cagnon and } \\
\text { Braissant }^{45}\end{array}$ & $\begin{array}{l}\text { Hyperammonemia-induced toxicity for } \\
\text { the developing central nervous system }\end{array}$ & $\begin{array}{l}\text { Authors suggest use acetyl-carnitine } \\
\text { in hyperammonemia }\end{array}$ & Meta-analysis & NA \\
\hline $\begin{array}{l}\text { Malaguarnera } \\
\text { et } \mathrm{al}^{42}\end{array}$ & $\begin{array}{l}\text { Acetyl L-carnitine treatment in elderly } \\
\text { patients with fatigue }\end{array}$ & $\begin{array}{l}\text { Acetyl-carnitine reduces fatigue and } \\
\text { age-related cognitive deficits }\end{array}$ & $\begin{array}{l}\text { Clinical trial, } \\
\text { randomized, } \\
\text { double-blind }\end{array}$ & 96 patients \\
\hline $\mathrm{Liu}^{43}$ & $\begin{array}{l}\text { Effects and mechanisms of mitochondrial } \\
\text { nutrient alpha-lipoic acid on improving } \\
\text { age-associated mitochondrial and } \\
\text { cognitive dysfunction: an overview }\end{array}$ & $\begin{array}{l}\text { Acetyl-carnitine reduces age-related } \\
\text { cognitive deficits }\end{array}$ & Overview & NA \\
\hline
\end{tabular}

on clinical, biochemical, ultrasonographic, or histological data. Exclusion criteria were overt hepatic encephalopathy, a history of recent alcohol intake, infection, recent antibiotic use, recent gastrointestinal bleeding, a history of recent use of drugs affecting psychometric performance (benzodiazepines, antiepileptics, or psychotropic drugs), a history of shunt surgery or a transjugular intrahepatic portosystemic shunt for portal hypertension, electrolyte imbalance, renal impairment, hepatocellular carcinoma, congestive heart failure, pulmonary disease, any neurological or psychiatric disorder that could influence measurement of quality of life, and inability to perform neuropsychological tests. A previous study also showed a significant improvement in cognitive function. ${ }^{40}$ Antidepressive activity in a geriatric population ${ }^{41}$ and reduced chronic physical and mental fatigue were reported, as well as a reduction in the cognitive deficits often associated with age. ${ }^{42,43}$ Acetyl-L-carnitine has also been proposed for the treatment of neurodegenerative diseases, such as Alzheimer's disease $^{44}$ and hyperammonemia, a rare disease that can cause irreversible damage to the central nervous system, atrophy, and cognitive deficits. ${ }^{45}$

\section{Choline alfoscerate and cognitive function}

Our systematic analysis identified a single article meeting our inclusion criteria (Table 6). Choline alfoscerate is a phospholipid necessary for construction of the cell membrane, and is capable of being rapidly absorbed as choline and crossing the blood-brain barrier. ${ }^{24}$ Moreover, it is the most active of the choline-containing phospholipids in increasing acetylcholine levels in the brain. ${ }^{5}$ Studies conducted before 2001, including a total of 1570 patients with dementia of vascular, degenerative, or mixed origin, showed that treatment with choline alfoscerate improved the clinical status of patients, particularly with regard to memory and attention. Compared with acetyl-carnitine, choline alfoscerate had better and more durable effects. ${ }^{23}$ Another meta-analysis of different therapeutic approaches evaluated the effect of various agents, ie, acetylcholine precursors, acetylcholine-releasing agents,

Table 6 Choline alfoscerate and cognitive function

\begin{tabular}{|c|c|c|c|c|}
\hline Reference & Title & Main results & Study type & $\begin{array}{l}\text { Patients } \\
\text { randomized }\end{array}$ \\
\hline Parnetti et $\mathrm{al}^{24}$ & $\begin{array}{l}\text { Cholinergic precursors in the } \\
\text { treatment of cognitive impairment } \\
\text { of vascular origin: ineffective } \\
\text { approaches or need for re-evaluation? }\end{array}$ & $\begin{array}{l}\text { Choline alfoscerate improves brain acetylcholine } \\
\text { levels and contributes to a modest improvement } \\
\text { of cognitive performances in patients with } \\
\text { vascular and neurodegenerative dementia }\end{array}$ & Review & NA \\
\hline
\end{tabular}


muscarinic and nicotinic receptor agonists, and cholinesterase inhibitors. This study reported that the precursors used most often, ie, choline and lecithin, are not likely to increase acetylcholine levels in the brain, but that choline alfoscerate might have this ability. ${ }^{24}$

In a novel pilot study, called ASCOMALVA (association between a cholinesterase inhibitor and a cholinergic precursor, choline alfoscerate, on cognitive deficits in Alzheimer's disease associated with cerebrovascular injury), treatment of patients with donepezil ${ }^{46}$ and choline alfoscerate resulted in more improvement in scores on several scales (Mini-Mental State Examination, Activities of Daily Living, Neuropsychiatric Inventory) than with donepezil alone after 3 and 6 months of treatment. Patients were selected if they had a diagnosis of Alzheimer's disease associated with vascular damage using National Institute of Neurological and Communicative Disorders and Stroke and Alzheimer's Disease and Related Disorders Association criteria. The inclusion criteria for this study were: age older than 50 years; Mini-Mental State Examination score 24-12; score $\geq 2$ on the New Rating Scale for Age-Related White Matter Changes, a rating scale for cerebral ischemic injury evaluated with computed tomography and/or brain magnetic resonance imaging; and presence of at least two vascular risk factors, ie, hypertension, diabetes, obesity, ischemic heart disease, dyslipidemia, hyperhomocysteinemia, smoking, previous cerebrovascular events, and family history of cardiovascular or cerebrovascular disease. Exclusion criteria were decompensated heart disease, chronic renal failure, severe liver failure, incorrect dysthyroidism, developmental disorders (eg, cancer), conditions that could interfere with safety and/or efficacy assessments, and a diagnosis of major depression according to Diagnostic and Statistical Manual of Mental Disorders, Fourth Edition, Text Revision (DSM-IV-TR) criteria. Preliminary results from the ASCOMALVA trial suggest that choline alfoscerate, associated with standard cholinesterase inhibitor therapy, may represent a therapeutic option for improve the beneficial effects of cholinergic therapy in patients with Alzheimer's disease and concurrent cerebrovascular damage.

\section{Nootropics and vascular dementia}

Vascular dementia is one of the most common forms of dementia. It is estimated that at least four of every 100 individuals of mean age 65 years suffer from vascular dementia, ${ }^{47}$ and that this number increases to around $16 \%$ by 80 years of age. ${ }^{48}$

\section{Citicoline}

No drug has been identified as yet as being an effective treatment for vascular dementia. ${ }^{49}$ For this reason, attempts are ongoing to find products capable of reducing the various cognitive deficits that develop in patients with this disorder. Citicoline may be one of these agents. It was found experimentally that citicoline could contribute to neural repair, ${ }^{50,51}$ and that it had neuroprotective effects in patients with neurodegenerative and cerebrovascular disease. A 6-month study in patients with ischemic stroke showed that citicoline prevented post-ictal cognitive decline, with a significant improvement in time orientation, attention, and executive function. ${ }^{50}$ Theoretically, citicoline is a safe and promising alternative compound for cognitive recovery following stroke, but at the moment the methodological heterogeneity of the relevant studies makes it difficult to draw unequivocal conclusions. ${ }^{51}$

\section{Cerebrolysin}

Cerebrolysin, a peptidergic compound with neurotrophic activity $^{52}$ and a well documented safety and tolerability profile, was also considered in our review. ${ }^{53}$ In a randomized, double-blind study, the effects of cerebrolysin $10 \mathrm{~mL}$ or $30 \mathrm{~mL}$ at 4 and 16 weeks were evaluated using two primary endpoints, ie, Alzheimer's Disease Assessment Scale-Cognitive (ADAS-cog) scores and slowing of the electroencephalographic pattern. The study yielded good results and showed beneficial effects on cognitive function, even at 12 weeks after discontinuation of treatment. ${ }^{52}$ These results were confirmed by a multicenter, double-blind, case-control study in which 242 patients were assigned to receive cerebrolysin $20 \mathrm{~mL}$ or placebo and underwent neuropsychological assessment using the ADAS-cog and Clinician Interview-Based Impression of Severity scales before and after 24 weeks of treatment. Inclusion criteria were a diagnosis of vascular dementia based on NINDSAIREN (National Institute of Neurologic Disorders and Stroke Association Internationale pour la Recherché et l'Enseignement en Neurosciences) criteria and confirmed by computed tomography or magnetic resonance imaging. Patients with mild to moderately severe dementia (Mini-Mental State Examination score 10-24) and a modified Hachinski ischemic score $>4$ and a Hamilton Depression Rating Scale score $\geq 15$ were included. Patients with severe concomitant neurologic or psychiatric illness were excluded, along with patients with any significant systemic illness or unstable medical condition that could lead to difficulty in complying with the protocol and those a history of systemic cancer within the preceding 2 years. In this study, significant improvements were obtained in ADAS-cog and Clinician 
Table 7 Nootropics and vascular dementia

\begin{tabular}{|c|c|c|c|c|}
\hline Reference & Title & Main results & Study type & $\begin{array}{l}\text { Patients } \\
\text { randomized }\end{array}$ \\
\hline $\begin{array}{l}\text { Alvarez-Sabín } \\
\text { and Román }\end{array}$ & $\begin{array}{l}\text { Citicoline in vascular cognitive impairment } \\
\text { and vascular dementia after stroke }\end{array}$ & $\begin{array}{l}\text { Citicoline prevents cognitive decline after } \\
\text { stroke and improves time orientation, } \\
\text { attention and executive functions }\end{array}$ & Review & NA \\
\hline $\begin{array}{l}\text { García-Cobos } \\
\text { et } a^{51}\end{array}$ & $\begin{array}{l}\text { Citicoline, use in cognitive decline: } \\
\text { vascular and degenerative }\end{array}$ & $\begin{array}{l}\text { Citicoline improves recovery and } \\
\text { cognitive improvement after stroke }\end{array}$ & Review & NA \\
\hline $\begin{array}{l}\text { Muresanu } \\
\text { et } \mathrm{al}^{52}\end{array}$ & $\begin{array}{l}\text { Persistence of the effects of cerebrolysin } \\
\text { on cognition and qEEG slowing in vascular } \\
\text { dementia patients: results of a } 3 \text {-month } \\
\text { extension study }\end{array}$ & $\begin{array}{l}\text { Cerebrolysin produces significant } \\
\text { improvements in cognitive function }\end{array}$ & $\begin{array}{l}\text { Clinical trial, } \\
\text { randomized, } \\
\text { double-blind }\end{array}$ & 33 patients \\
\hline $\begin{array}{l}\text { Guekht } \\
\text { et } \mathrm{al}^{53}\end{array}$ & $\begin{array}{l}\text { Cerebrolysin in vascular dementia: } \\
\text { improvement of clinical outcome } \\
\text { in a randomized, double-blind, } \\
\text { placebo-controlled multicenter trial }\end{array}$ & $\begin{array}{l}\text { Cerebrolysin produces significant } \\
\text { improvements in cognitive function }\end{array}$ & $\begin{array}{l}\text { Clinical trial, } \\
\text { randomized, } \\
\text { double-blind }\end{array}$ & 242 patients \\
\hline
\end{tabular}

Interview-Based Impression of Severity scores, pointing to cognitive improvement (Table 7)..$^{53}$

\section{Nootropics and Alzheimer's disease Cerebrolysin}

Use of cerebrolysin has been proposed for Alzheimer's disease, and published studies seem to be promising. ${ }^{54}$ A randomized, double-blind, case-control study in patients with moderate to severe Alzheimer's disease showed encouraging effects both on global cognitive function (measured with ADAS-cog) and on behavioral symptoms, for all doses used, ie, $10 \mathrm{~mL}, 30 \mathrm{~mL}$, or $60 \mathrm{~mL}$, at 12 and 24 weeks after the baseline evaluation. ${ }^{28}$ However, no significant changes were observed in Mini-Mental State Examination score or in the Trail Making Test.

\section{Crocus sativus}

Another recent study in 54 subjects has tested Crocus sativus $30 \mathrm{mg} /$ day versus donepezil $10 \mathrm{mg}$ /day for 22 weeks in patients with mild to moderate Alzheimer's disease. Inclusion criteria were mild-to-moderate dementia (Mini-Mental State Examination score 15-26). Patients were required to be ambulatory and have sufficient hearing and vision to comply with assessments. Previous treatment with cholinesterase inhibitors, memantine, ginkgo, or saffron had to have been discontinued at least 3 months before randomization. Patients with any of the following conditions were excluded from the study: known hypersensitivity to cholinesterase inhibitors, active and uncontrolled disease (diabetes, hypertension, thyroid disease, obstructive pulmonary disease), hematologic/ oncologic disorders within the previous 12 months, active

Table 8 Nootropics and Alzheimer's disease

\begin{tabular}{|c|c|c|c|c|}
\hline Reference & Title & Main results & Study type & $\begin{array}{l}\text { Patients } \\
\text { randomized }\end{array}$ \\
\hline Alvarez et $\mathrm{al}^{28}$ & $\begin{array}{l}\text { Efficacy and safety of cerebrolysin in moderate } \\
\text { to moderately severe Alzheimer's disease: } \\
\text { results of a randomized, double-blind, controlled } \\
\text { trial investigating three dosages of cerebrolysin }\end{array}$ & $\begin{array}{l}\text { Cerebrolysin is effective for global } \\
\text { cognitive function and behavioral } \\
\text { symptoms }\end{array}$ & $\begin{array}{l}\text { Clinical trial, } \\
\text { randomized, } \\
\text { double-blind }\end{array}$ & 133 patients \\
\hline $\begin{array}{l}\text { Plosker and } \\
\text { Gauthier }\end{array}$ & Cerebrolysin: a review of its use in dementia & $\begin{array}{l}\text { Promising results with cerebrolysin } \\
\text { in patients with Alzheimer's disease }\end{array}$ & Review & NA \\
\hline $\begin{array}{l}\text { Akhondzadeh } \\
\text { et } \mathrm{al}^{55}\end{array}$ & $\begin{array}{l}\text { A 22-week, multicenter, randomized, } \\
\text { double-blind controlled trial of Crocus sativus } \\
\text { in the treatment of mild-to-moderate } \\
\text { Alzheimer's disease }\end{array}$ & $\begin{array}{l}\text { Provides preliminary evidence of a } \\
\text { possible therapeutic effect of saffron } \\
\text { extract in treatment of patients with } \\
\text { mild-to moderate Alzheimer's disease }\end{array}$ & $\begin{array}{l}\text { Clinical trial, } \\
\text { randomized, } \\
\text { double-blind }\end{array}$ & 54 patients \\
\hline $\begin{array}{l}\text { Schaeffer } \\
\text { et } \mathrm{al}^{57}\end{array}$ & $\begin{array}{l}\text { Phospholipase A2 activation as a therapeutic } \\
\text { approach for cognitive enhancement in } \\
\text { early-stage Alzheimer's disease }\end{array}$ & $\begin{array}{l}\text { Phospholipase A2 could be a valid } \\
\text { therapeutic strategy for cognitive } \\
\text { enhancement in early-stage } \\
\text { Alzheimer's disease }\end{array}$ & Review & NA \\
\hline Yurko-Mauro 56 & $\begin{array}{l}\text { Cognitive and cardiovascular benefits } \\
\text { of docosahexaenoic acid in aging and } \\
\text { cognitive decline }\end{array}$ & $\begin{array}{l}\text { Docosahexaenoic acid has significant } \\
\text { positive effects on verbal recognition } \\
\text { memory }\end{array}$ & $\begin{array}{l}\text { Clinical trial, } \\
\text { randomized, } \\
\text { double-blind }\end{array}$ & 485 patients \\
\hline
\end{tabular}


gastrointestinal, renal, hepatic, endocrine, or cardiovascular disease, a current DSM-IV-TR diagnosis of major depressive disorder or any current primary psychiatric diagnosis other than Alzheimer's disease and dementia complicated by delirium or a history of drug or alcohol abuse within the past 2 years. In this study, Crocus sativus was as effective as donepezil, but had fewer side effects. ${ }^{55}$

\section{Docosahexaenoic acid}

Docosahexaenoic acid has also been used in the treatment of Alzheimer's disease. One randomized, double-blind, case-control study showed significantly positive effects on verbal recognition, indicating a potentially positive role in preventing or relieving cognitive decline. ${ }^{56}$

\section{Phospholipase A2}

Similar results were found for phospholipase A2 (especially cPLA2 and iPLA2), which could be a good therapeutic strategy for cognitive improvement in the early stages of the disease (Table 8$).{ }^{57}$

\section{Conclusion}

The data reported here indicate that nootropics may be an effective alternative in strengthening and enhancing cognitive performance in patients with a range of brain pathologies. Piracetam, with its near absence of side effects, has shown cerebroprotective activity as well as an ability to reduce cognitive deficits subsequent to general anesthesia. More extensive studies are needed for oxiracetam, because the currently available data are limited and, in some cases, contradictory.

Regarding cholinergic precursors, not all the data are positive. Lecithin does not seem to achieve significant improvement in cognitive functioning. The same is not true for citicoline or choline alfoscerate. Citicoline has neuroprotective effects, especially in patients with stroke and traumatic brain injury, probably by helping repair processes in the neural membrane, reducing the accumulation of lipids, and increasing acetylcholine levels. Citicoline also improves cognition, particularly motor and attentive functioning, in patients with dementia. Acetyl-carnitine is associated with an increase in energy and well-being by reducing physical and psychological fatigue. Further, acetyl-carnitine has demonstrated an antidepressive effect. Choline alfoscerate also enhances cognitive functioning and is, among several precursors, active in increasing acetylcholine levels in the brain. Therefore, it may represent a therapeutic option to improve the beneficial effects of cholinergic therapy in patients with Alzheimer's disease and concomitant cerebrovascular damage.
In summary, although the nootropics and in particular the cholinergic precursors, already have a long history behind them, they still seem to have a significant role in pharmacology, as reflected in a recent renewal of interest. This is true primarily in dementia disorders, in which the only classes of drugs widely used, ie, cholinesterase inhibitors and memantine, have had mixed and often transient results.

\section{Disclosure}

The authors report no conflicts of interest in this work.

\section{References}

1. Malykh AG, Sadaie MR. Piracetam and piracetam-like drugs: from basic science to novel clinical applications to CNS disorders. Drugs. 2010;70:287-312.

2. Amenta F, Tayebati SK. Pathways of acetylcholine synthesis, transport and release as targets for treatment of adult-onset cognitive dysfunction. Curr Med Chem. 2008;15:488-498.

3. Brown DA. Acetylcholine. Br J Pharmacol. 2006;147 Suppl 1: S120-S126.

4. Terry AV Jr, Buccafusco JJ. The cholinergic hypothesis of age and Alzheimer's disease-related cognitive deficits: recent challenges and their implications for novel drug development. J Pharmacol Exp Ther. 2003;306:821-827.

5. Amenta F, Parnetti L, Gallai V, Wallin A. Treatment of cognitive dysfunction associated with Alzheimer's disease with cholinergic precursors. Ineffective treatments or inappropriate approaches? Mech Ageing Dev. 2001;122:2025-2040.

6. Wells G, Shea B, O'Connell D, et al; The Newcastle-Ottawa Scale (NOS) for assessing the quality of nonrandomized studies in metaanalysis. Ottawa: Ottawa Hospital Research Institute; 2011. Available from: http://www.ohri.ca/programs/clinical_epidemiology/oxford.asp. Accessed October 7, 2012.

7. Fedi M, Reutens D, Dubeau F, et al. Long-term efficacy and safety of piracetam in the treatment of progressive myoclonus epilepsy. Arch Neurol. 2001;58:781-786.

8. Waegemans T, Wilsher CR, Danniau A, et al. Clinical efficacy of piracetam in cognitive impairment: a meta-analysis. Dement Geriatr Cogn Disord. 2002;13:217-224.

9. Nickolson VJ, Wolthuis OL. Effect of the acquisition-enhancing drug piracetam on rat cerebral energy metabolism: comparison with naftidrofuryl and methamphetamine. Biochem Pharmacol. 1976;25:2241-2244.

10. Grau M, Montero JL, Balasch J. Effect of piracetam on electrocorticogram and local cerebral glucose utilization in the rat. Gen Pharmacol. 1987;18:205-211.

11. Fesenko UA. Piracetam improves children's memory after general anaesthesia. Anestezjol Intens Ter. 2009;41:16-21. Polish.

12. McKhann GM, Goldsborough MA, Borowicz LM Jr, et al. Cognitive outcome after coronary artery bypass: a one-year prospective study. Ann Thorac Surg. 1997;63:510-515.

13. Bruggemans EF, Van Dijk JG, Huysmans HA. Residual cognitive dysfunctioning at 6 months following coronary artery bypass graft surgery. Eur J Cardiothorac Surg. 1995;9:636-643.

14. Holinski S, Claus B, Alaaraj N, et al. Cerebroprotective effect of piracetam in patients undergoing coronary bypass surgery. Med Sci Monit. 2008;14:153-157.

15. Szalma I, Kiss A, Kardos L, et al. Piracetam prevents cognitive decline in coronary artery bypass: a randomized trial versus placebo. Ann Thorac Surg. 2006;82:1430-1435. 
16. Uebelhack R, Vohs K, Zytowski M, et al. Effect of piracetam on cognitive performance in patients undergoing bypass surgery. Pharmacopsychiatry. 2003;36:89-93.

17. Jelic V, Kivipelto M, Winblad B. Clinical trials in mild cognitive impairment: lessons for the future. J Neurol Neurosurg Psychiatry. 2006;77:429-438.

18. Holinski S, Claus B, Alaaraj N, et al. Cerebroprotective effect of piracetam in patients undergoing open heart surgery. Ann Thorac Cardiovasc Surg. 2011;17:137-142.

19. Lobaugh NJ, Karaskov V, Rombough V, et al. Piracetam therapy does not enhance cognitive functioning in children with Down syndrome. Arch Pediatr Adolesc Med. 2001;155:442-448.

20. Kessler J, Thiel A, Karbe H, et al. Piracetam improves activated blood flow and facilitates rehabilitation of poststroke aphasic patients. Stroke 2000;31:2112-2116.

21. Rozzini R, Zanetti O, Bianchetti A. Treatment of cognitive impairment secondary to degenerative dementia: effectiveness of oxiracetam therapy. Acta Neurol (Napoli). 1993;15:44-52.

22. Green RC, Goldstein FC, Auchus AP, et al. Treatment trial of oxiracetam in Alzheimer's disease. Arch Neurol. 1992;49:1135-1136.

23. Parnetti L, Amenta F, Gallai V. Choline alphoscerate in cognitive decline and in acute cerebrovascular disease: an analysis of published clinical data. Mech Ageing Dev. 2001;122:2041-2055.

24. Parnetti L, Mignini F, Tomassoni D, Traini E, Amenta F. Cholinergic precursors in the treatment of cognitive impairment of vascular origin: ineffective approaches or need for re-evaluation? J Neurol Sci. 2007;257:264-269.

25. Domino EF, Mathews BN, Tait SK, Ortiz A. Effects of oral phosphatidylcholine on mouse brain choline and acetylcholine. Arch Int Pharmacodyn Ther. 1983;265:49-54.

26. Adibhatla RM, Hatcher JF, Dempsey RJ. Cytidine-5'-diphosphocholine (CDP-choline) affects CTP: phosphocholine cytidylyl transferase and lyso-phosphatidylcholine after transient brain ischemia. J Neurosci Res. 2004;76:390-396.

27. D’Orlando KJ, Sandage BW Jr. Citicoline (CDP-choline): mechanisms of action and effects in ischemic brain injury. Neurol Res. $1995 ; 17: 281-284$

28. Alvarez XA, Cacabelos R, Sampedro C, et al. Efficacy and safety of cerebrolysin in moderate to moderately severe Alzheimer's disease: results of a randomized, double-blind, controlled trial investigating three dosages of cerebrolysin. Eur J Neurol. 2011;18: 59-68.

29. Secades JJ. Citicoline: pharmacological and clinical review. Rev Neurol. 2010;52 Supp1 2:S1-S62. Spanish.

30. Fioravanti M, Yanagi M. Cytidinediphosphocholine (CDP choline) for cognitive and behavioural disturbances associated with chronic cerebral disorders in the elderly. Cochrane Database Syst Rev. 2004;2:CD000269.

31. Renshaw PF, Babb SM, Yurgelun-Todd DA, Wald LL, Villafuerte RA, Cohen BM. Chronic citicholine (CDP-choline) administration alters brain phospholipid metabolites and improves cognitive performance in healthy, older adults. Presented at the 37th American College of Neuropsychopharmacology Annual Meeting; September 14-18, 1998; San Juan, Puerto Rico.

32. Agnoli A, Fioravanti M, Lechner H. Efficacy of CDP choline in chronic cerebral vascular diseases. In: Zappia V, Kennedy EP, Nilsson BI, Galletti P, editors. Novel Biochemical, Pharmacological and Clinical Aspects of Cytidinediphosphocholine. Amsterdam: Elsevier Science Publishing; 1985.

33. Sinforiani E, Trucco M, Pacchetti C, Gualtieri S. Valutazione degli effetti della citicolina nella malattia cerebro-vascolare cronica [Evaluation of citicoline effects in cerebrovascular disease]. Minerva Med. 1986;77:51-57. Italian.

34. Motta L, Fichera G, Tiralosi G, Di Stefano A. La citicolina nel trattamento delle cerebrovasculopatie croniche [Citicoline in the treatment of chronic cerebrovascular disease]. G Gerontol. 1986;34:149-158. Italian.
35. Tanaka Y, Minematsu K, Hirano T, Hayashida K, Yamaguchi T. Effects of CDP-choline on dynamic changes in LCBF and cognitive function in demented subjects. An H2 15O-PET study. Rinsho Shinkeigaku. 1994;34:877-881.

36. Caamaño J, Gómez MJ, Franco A, Cacabelos R. Effects of CDP-choline on cognition and cerebral hemodynamics in patients with Alzheimer's disease. Methods Find Exp Clin Pharmacol. 1994;16:211-218.

37. Vale S. Current management of the cognitive dysfunction in Parkinson's disease: how far have we come? Exp Biol Med (Maywood). 2008;233:941-951.

38. Dhiman RK, Chawla YK. Minimal hepatic encephalopathy. Indian J Gastroenterol. 2009;28:5-16.

39. Malaguarnera M, Bella R, Vacante M, et al. Acetyl-L-carnitine reduces depression and improves quality of life in patients with minimal hepatic encephalopathy. Scand J Gastroenterol. 2011;46:750-759.

40. Malaguarnera M, Gargante MP, Cristaldi E, et al. Acetyl-L-carnitine treatment in minimal hepatic encephalopathy. Dig Dis Sci. 2008;53: 3018-3025.

41. Soczynska JK, Kennedy SH, Chow CS, Woldeyohannes HO, Konarski JZ, McIntyre RS. Acetyl-L-carnitine and alpha-lipoic acid: possible neurotherapeutic agents for mood disorders? Expert Opin Investig Drugs. 2008;17:827-843.

42. Malaguarnera M, Gargante MP, Cristaldi E, et al. Acetyl L-carnitine (ALC) treatment in elderly patients with fatigue. Arch Gerontol Geriatr. 2008;46:181-190.

43. Liu J. The effects and mechanisms of mitochondrial nutrient alphalipoic acid on improving age-associated mitochondrial and cognitive dysfunction: an overview. Neurochem Res. 2008;33:194-203.

44. Mancuso C, Bates TE, Butterfield DA, et al. Natural antioxidants in Alzheimer's disease. Expert Opin Investig Drugs. 2007;16:1921-1931.

45. Cagnon L, Braissant O. Hyperammonemia-induced toxicity for the developing central nervous system. Brain Res Rev. 2007;56:183-197.

46. Amenta F, Carotenuto A, Fasanaro G, Lanari A, Rea R, Traini E. Preliminary results of Ascomalva trial on the association of donepezil and choline alphoscerate in Alzheimer's disease with associated cerebrovascular injury. G Gerontol. 2011;59:89-98. Italian.

47. Malouf R, Birks J. Donepezil for vascular cognitive impairment. Cochrane Database Syst Rev. 2004;1:CD004395.

48. Roman GC. Vascular dementia revisited: diagnosis, pathogenesis, treatment, and prevention. Med Clin N Am. 2002;86:477-499.

49. Pantoni L. Treatment of vascular dementia: evidence from trials with non-cholinergic drugs. J Neurol Sci. 2004;226:67-70.

50. Alvarez-Sabín J, Román GC. Citicoline in vascular cognitive impairment and vascular dementia after stroke. Stroke. 2011;42(Suppl 1) S40-S43.

51. García-Cobos R, Frank-García A, Gutiérrez-Fernández M, Díez-Tejedor E. Citicoline, use in cognitive decline: vascular and degenerative. J Neurol Sci. 2010;299:188-192.

52. Muresanu DF, Alvarez XA, Moessler H, et al. Persistence of the effects of cerebrolysin on cognition and qEEG slowing in vascular dementia patients: results of a 3-month extension study. J Neurol Sci. 2010;299:179-183.

53. Guekht AB, Moessler H, Novak PH, Gusev EI; Cerebrolysin Investigators. Cerebrolysin in vascular dementia: improvement of clinical outcome in a randomized, double-blind, placebo-controlled multicenter trial. J Stroke Cerebrovasc Dis. 2011;20:310-318.

54. Plosker GL, Gauthier S. Cerebrolysin: a review of its use in dementia. Drugs Aging. 2009;26:893-915.

55. Akhondzadeh S, Shafiee Sabet M, Harirchian MH, Togha M. A 22-week, multicenter, randomized, double-blind controlled trial of Crocus sativus in the treatment of mild-to-moderate Alzheimer's disease. Psychopharmacology (Berl). 2010;207:637-643.

56. Yurko-Mauro K. Cognitive and cardiovascular benefits of docosahexaenoic acid in aging and cognitive decline. Curr Alzheimer Res. 2010;7:190-196.

57. Schaeffer EL, Forlenza OV, Gattaz WF. Phospholipase A2 activation as a therapeutic approach for cognitive enhancement in early-stage Alzheimer disease. Psychopharmacology (Berl). 2009;202:37-51. 
Journal of Experimental Pharmacology

Dovepress

\section{Publish your work in this journal}

The Journal of Experimental Pharmacology is an international, peerreviewed, open access journal publishing original research, reports, reviews and commentaries on all areas of laboratory and experimental pharmacology. The manuscript management system is completely online and includes a very quick and fair peer-review system.

Visit http://www.dovepress.com/testimonials.php to read real quotes from published authors. 